\title{
Conclusion: Japan's Search for a New Direction in Peacekeeping
}

\section{The Trajectories of Japan's Peacekeeping Policy}

\subsection{Overview of Japan's Peacekeeping Policy}

This book has considered the evolution of Japan's peacekeeping policy, with special heed to a quarter-century period of troop contribution to the UNPKOs from 1992 to 2017. A main hypothetical assumption of this book was that Japan's peacekeeping policy had evolved in pursuit of "robustness" and "integration" to follow international trends in UNPKOs with the hope of making a more "proactive" contribution to these UNPKOs. By the late 2010s, however, Japan's efforts had reached a deadlock, in terms of both "robustness" and "integration," resulting in the 2017 termination of troop contributions.

With this in mind, Chap. I reviewed the evolution of Japan's peacekeeping policy and the changing global trends in UNPKOs that developed in parallel. It highlighted the deep gap between the Japanese legal system and the international UNPKO trends and how this motivated the GoJ to try to catch up with the "global standard." This introductory chapter also pointed out that recent years have seen the rise of widespread hesitation toward troop contribution to the UNPKOs among the countries of the Global North. In doing so, it indicated that the discontinuity of Japan's troop contribution should be regarded in the context of this common trend in the Global North. In Chap. 2, we mapped the historical background of Japan's peacekeeping policy from the early postwar period to 1992, clarifying how anti-militarism, especially the de facto national ban

(C) The Author(s) 2022

H. N. Fujishige et al., Japan's Peacekeeping at a Crossroads, Sustainable Development Goals Series, https://doi.org/10.1007/978-3-030-88509-0_9 
on overseas military dispatch, had prevented the postwar Japan from contributing troops to the UNPKOs. The chapter then showed how the changes around the end of the Cold War drastically pushed Japan to enact a highly ambitious PKO Act in 1992. Next, Chap. 3, which covered the era from 1992 to 2012, articulated Japan's actual performance under the narrow and broader IPC frameworks, the moves and challenges toward "integration" and "robustness," and the decline of anti-militarism. It also examined the constraints embedded in the statute, represented by the Five Principles. Chapter 4 then focused on more recent developments under the second Abe administration, paying special heed to the impacts of the Peace and Security Legislation in 2015. After providing an overview of Abe's wholesale reform of security policy, the chapter paid special attention to the pursuit of "robustness" and "integration" during this period.

The latter half of this book presented selected case studies of Japan's peacekeeping experience, especially those examples with high relevance to the national pursuit of "robustness" and "integration." Chapter 5 analyzed Japan's first ever military contribution to a UNPKO, which was in Cambodia from 1992 to 1993. In this case, both the GoJ and Japanese peacekeepers on site were perplexed by the harsh empirical reality of the UNPKO, creating challenges that culminated in the loss of two Japanese personnel. This bitter experience led to the subsequent pursuit of "robustness" in future peacekeeping policy, particularly in terms of the protection of Japanese nationals on the ground. At the same time, national moves toward greater "integration" also emerged, after the JEG's successful engineering contribution to the Cambodia operation.

Chapter 6 examined the case of East Timor in the early 2000s, which was an experience of peacekeeping while also building a new state. Emphasizing core statebuilding activities, this case further advanced the pursuit of greater "integration," especially by employing the "All Japan" approach. While in East Timor, a security incident occurred, forcing the JEG to engage in the de facto rescue of Japanese nationals during mass demonstrations, which simultaneously reaffirmed the need to adopt greater "robustness" in Japanese peacekeeping policy.

Chapter 7 evaluated the case of Haiti in the early 2010s, which occurred under conditions of complex crisis that combined natural disaster with serious insecurity, accompanied by a violent political conflict. When the great earthquake in 2010 triggered the GoJ's assistance to Haiti, a more sophisticated version of multilayered civil-military cooperation was seen than in the earlier cases, such as East Timor, further enhancing the trend 
of "integration." Although serious security concerns existed in Haiti, especially in the post-earthquake confusion, the Japanese civilian medical team was able to safely complete their mission. Regardless, the Haitian experience raised important questions concerning how to protect civilian aid workers in insecure conditions.

Lastly, Chap. 8 investigated the case of South Sudan from 2012 to 2017. For the first two years, when UNMISS primarily concentrated on statebuilding, the JEG was able to focus on civil construction work, which created positive outcomes toward "integration." With the outbreak of de facto civil war at the end of 2013, however, UNMISS's mandate was eventually switched to the PoC. Serious insecurity on the ground inevitably made the GoJ face up to the pressing need for greater "robustness" of its peacekeeping forces. Concurrent with on-site changes, the 2015 Peace and Security Legislation also amended the PKO Act to include the partial relaxation of restrictions on the use of weapons by SDF peacekeepers. In fall 2016, the JEG was assigned these two newly added security-related duties, namely the "coming-to-aid" and "joint defense of a camp" duties. However, the JEG was abruptly withdrawn from South Sudan half a year later, before performing these new duties. Since then, the GoJ has contributed no subsequent troops to any UNPKO, although the deployment of a small number of staff officers to UNMISS is still maintained to this day.

\subsection{Japan's Peacekeeping Policy at a Crossroads}

Since its UNPKO debut in 1992, Japan has cautiously sought to catch up with global trends in UNPKOs, namely concurrent trends toward greater "robustness" and "integration," in order to reduce the gap between the Japanese legal system and international standards. This is the basis of common assumptions that more "proactive" troop deployment, especially in terms of quantity, would be a desirable national policy goal. The dual pursuit of greater "robustness" and "integration" evolved together to eventually construct a uniquely Japanese way of peacekeeping. After a quarter century, however, both trends had reached their limits, resulting in the abrupt termination of peacekeeping troop contributions in 2017.

From the analysis in the preceding chapters, we can say that Japan's peacekeeping policy now stands at a crossroads. In the early days of the second Abe administration, it seemed that moves toward both greater "robustness" and greater "integration" were well promoted. In line with the trend toward "robustness," the 2015 amendment to the PKO Act as 
part of the Peace and Security Legislation expanded the scope for the use of weapons beyond the narrow self-preservation purpose, commonly known as the addition of the "coming-to-aid" duty. In line with the trend toward "integration," on the other hand, the Abe administration promoted the "All Japan" approach, which combined peacekeeping efforts with development aid in Haiti and South Sudan. Despite these efforts and achievements, the JEG withdrew from South Sudan in May 2017. Why have these efforts reached a stalemate? We will consider these questions below.

\section{The Consequences of Japan's Dual Pursuit of "Robustness" and "Integration"}

\subsection{The Consequence of the Pursuit of "Robustness"}

From the outset, the pursuit of "robustness," particularly in terms of relaxation of the use of weapons, was the central concern in the evolution of Japan's peacekeeping policy. The use of weapons had always been an exceptionally intractable problem for the GoJ, since this could constitute a situation of the use of force, which is banned by the Constitution. With the initial adoption of the PKO Act in 1992, the GoJ had already imposed extremely strict constraints on the use of weapons for any future SDF peacekeepers. As a result, the range of authorized weapons use permitted to SDF personnel was much narrower than the global standard practiced in various UNPKOs. Japan's self-imposed restrictions were put in place almost entirely to satisfy domestic legal requirements and to defuse the anti-military political opposition, as well as the very strong reluctance within the SDF to expose its personnel to danger. These restrictions generated serious gaps between Japan's national caveats and the general standards in the UNPKOs: gaps that were soon highlighted in Japan's actual experience of military contributions in Cambodia, East Timor, and elsewhere. This raised calls in Japan to relax overly stringent legal constraints and instead try to follow changing trends toward greater "robustness" at the international level.

In this context, the PKO Act was amended in 1998, 2001, and 2015 to loosen the limits on the use of weapons gradually, albeit only to a minimal extent. Most notably, the new "coming-to-aid" duty was introduced under the amendment to the PKO Act that occurred as part of the 
all-inclusive Peace and Security Legislation in 2015. This new rescue duty provoked much controversy, partly because it would allow the SDF peacekeepers to use weapons beyond the narrow scope of self-preservation and partly because it was actually assigned to the JEG in the highly volatile South Sudan in November 2017. After the subsequent half year of rising domestic pressure and political criticism, and also triggered by the disclosure of a hidden JEG report, the GoJ withdrew the JEG from South Sudan in May 2017 without ever performing the "coming-to-aid" duty in practice.

In retrospect, how should we evaluate the GoJ's pursuit of "robustness" throughout its quarter-century history of peacekeeping? To begin answering this question, we can point out that, from the beginning, the GoJ was not very enthusiastic regarding the move toward greater "robustness," or at best remained a hesitant pursuer of this larger trend. Two main factors facilitated the relaxation of restrictions on the use of weapons: the call for a more "proactive" personnel contribution, especially in quantity; and the need to reduce the confusion of SDF peacekeepers on the ground. First, the relative weight of the peacekeeping issue in Japan's security and foreign policy had been to some extent declining. In the first half of the 1990s, the GoJ had a strong incentive to promote participation in the UNPKOs under the political slogan of "International Contribution." From the mid-1990s onward, however, both the GoJ and domestic public opinion had become increasingly concerned about regional stability in its neighborhood and preoccupied with the bilateral alliance relationship with the US. Commitment to the UNPKOs remained important to show Japan's willingness to cooperate with the UN, but this priority had been somewhat marginalized in comparison with the renewed attention to national security.

Second, from the GoJ's point of view, the use of weapons in peacekeeping had always been a highly challenging problem that risked inviting fierce anti-military criticism. Notwithstanding the decline in anti-militarism over the last few decades, the ban on the use of force remains resolute, because it is firmly institutionalized in the Constitution. Although traditional anti-military parties currently occupy only a marginal status in the Diet, they might regain public support whenever an issue arrives at the very delicate point of potentially infringing on the Constitution. This was typically seen in the case of a large-scale opposition campaign against the Peace and Security Legislation in 2015. Put another way, the "use of weapons" in peacekeeping could be too politically risky an agenda for the 
GoJ, potentially weakening its political power. Given these reasons, the GoJ had not necessarily been willing to relax restrictions on the use of weapons in peacekeeping. Even when they did relax the rules, they did so only to a minimal extent.

This was particularly the case in the controversy surrounding the 2015 amendment to the PKO Act. The addition of new tasks, especially the "coming-to-aid" duty, caused much debate in Japan, since it marked a qualitative departure in Japan's peacekeeping policy by allowing the use of weapons beyond the scope of self-preservation to the new category of "execution of missions" (see Chaps. 3 and 4). From an international point of view, the UN standard typically allows what the Japanese call "comingto-aid" duty as part of the broader right to self-defense. For this reason, the policy recommendations of expert panels in 2002, 2008, and 2014 demanded that "coming-to-aid" duty should be legalized as an aspect of self-preservation (Chaps. 3 and 4; The Security Experts Panel, 2014, p. 29). If so, the addition of "coming-to-aid" duty would mean the expansion of the allowed range for self-preservation to the extent of the global standard of "self-defense."

Nonetheless, Prime Minister Abe declined this difficult job and compromised by authorizing the "coming-to-aid" duty not as part of selfpreservation but under the category of "execution of missions." In other words, even after the addition of the "coming-to-aid" duty, Japan's standard for the use of weapons in peacekeeping still remained distant from that found in the UNPKOs. Moreover, even the range of the newly added "coming-to-aid" duty was much narrower than that of similar activities at the international level, prohibiting the use of weapons against a state or quasi-state organization as an adversary party.

If the "coming-to-aid" duty were legitimized for the self-preservation purpose, the SDF's use of weapons for the "coming-to-aid" duty could be allowed whatever their target, including a state or quasi-state organization, because it rests on the natural rights of human beings. In reality, the "coming-to-aid" duty was legalized under the category of "the execution of missions," which meant that the SDF would not be allowed to use weapons against a state or quasi-state organization as an adversary party (see Chaps. 3 and 4). Under the confusion of post-conflict countries, however, it would be extremely difficult to make a clear distinction among state, quasi-state, and non-state organizations. To avoid the danger of violating the constitutional ban on the use of force, therefore, the allowed range for the JEG's use of weapons for "coming-to-aid" duty was 
confined to a limited extent. In a nutshell, the relaxation of restrictions on the use of weapons in Japan's peacekeeping was still much more limited in comparison with the "robustness" found in the UNPKOs.

\subsection{The Consequences of the Pursuit of "Integration"}

Unlike the rocky road that Japan's (reluctant) pursuit of "robustness" had traveled, the pursuit of greater "integration" had developed along a much more favored path. Focus on the engineering capability based on the "All Japan" approach was a perfect fit for Japan's requirements and abilities in peacekeeping. It not only was a safer option among the various types of troop contributions, but also enabled the GoJ to make maximum use of Japan's world-renowned engineering skills and economic power. It permitted the GoJ to avoid the political risk of inviting anti-military criticism while also making its unique contribution to the UNPKOs. In contrast to the pursuit of "robustness," which had varied between willingness and reluctance, a wider consensus existed in favor of advancing "integration" within the GoJ, on both the civilian and the military side. Moreover, both the UN and host nations had highly praised the JEG's construction works.

Overall, thus, Japan's move toward “integration" developed well. In the earlier cases, such as in Cambodia and East Timor, practical challenges were recognized, such as the need to include training provision for heavy machinery operators and mechanics following the donation of used equipment to host nations. The question of how the "All Japan" approach could be situated within the UN framework also appeared as a future agenda item. By accumulating on-site experiences, answers to this question were gradually found: for example, by bringing coordination SDF officers to the field, as typically seen in Haiti and South Sudan (see Chaps. 7 and 8). Technically, these coordinators were situated outside of the UN framework, but they worked closely with the SDF peacekeepers and facilitated communication with the UN field headquarters and the Japanese contingent. This scheme proved useful to establish a local development agenda, founded by JICA and its collaborators, as a part of UN duties. This helped the SDF peacekeepers to carry out the "All Japan" approach with tasking from the UN side.

In the meantime, the JEG could not entirely free itself from demands for greater "robustness," as particularly seen in Cambodia, East Timor, and South Sudan (see Chaps. 5, 6, and 8). The case of South Sudan especially highlighted the bitter reality of contemporary UNPKOs, among 
which few statebuilding-focused missions existed. Contemporary UNPKOs are often mandated with both "integration" and "robustness." In reality, as seen in UNMISS, the urgent concerns for the PoC mostly monopolized the practical attention of personnel on site. Coping with imminent danger is usually a top priority and it is therefore not easy to promote statebuilding activities in conditions of insecurity. This changing trend in the UNPKO had made it very difficult for the GoJ to maintain its personnel deployment for "integration," based above all on the "All Japan” approach.

\section{The Other Possible Explanations for the JEG's Sudden WithdraWal from South Sudan}

As seen above, we argue that the termination of Japan's troop contribution to the UNPKOs should be attributed to the stalemates in the GoJ's pursuit of both "robustness" and "integration." Besides, however, we can also point out several plausible explanations behind the Abe government's sudden decision to withdraw the JEG only half a year after it had been tasked with the "coming-to-aid" duty. As mentioned earlier, we do not yet have concrete evidence to answer this question, although we can reasonably assume that the divulgation of the daily reports was just a direct trigger.

Even a without tangible evidence, we may conjecturally suggest several possible reasons. First and the foremost, it seemed politically too risky for the Abe administration to maintain the JEG in the highly dangerous South Sudan with such a limited security duty, especially after the situation had been inflamed by the scandal surrounding the disclosure of daily reports. The addition of a "coming-to-aid" duty provoked heated debate only within the inward legal logic and it achieved a minor catch-up in terms of "robustness" at the international level.

Presumably, it was true that Abe was severely concerned about serious insecurity in South Sudan, especially following the recurrence of largescale violence in July 2016. Meanwhile, the PKO Act was amended in September 2015 and came into effect in March 2016. Originally, the GoJ was motivated to include the "coming-to-aid" duty in the 2015 amendment, based on the bitter experience in Zaire and East Timor, where the SDF had to perform the de facto "coming-to-aid" duty without a formal legal basis (see Chaps. 3 and 6). Needless to say, it was by no means 
undesirable that the military personnel would perform an unassigned task, while it would be practically very difficult to neglect a call for help from the Japanese personnel on site. This was the fundamental motivation behind the legalization of "coming-to-aid" duty in the 2015 amendment to the PKO Act.

While the Abe government was preparing for the amendment of the PKO Act as part of the Peace and Security Legislation, however, the security situation in South Sudan rapidly deteriorated. From this timing, we may reasonably surmise that the Abe government gradually changed its principle in the inclusion of "coming-to-aid" duty from just preparing for a future possibility to planning for an actual application to the JEG in South Sudan.

This shift was reinforced by the return of armed fighting in Juba in July 2016, three months after the 2015 amendment came into effect in March 2016. On the one hand, it was necessary to protect the Japanese nationals in South Sudan. On the other hand, the JEG existed in Juba and the "coming-to-aid" duty had already been legitimized when violence resurfaced in Juba. So, why not? In this way, the "coming-to-aid" duty was added in the 2015 amendment to the PKO Act partly to reduce the gap between the reality of UNPKOs and the national caveats. Moreover, with increasing insecurity in South Sudan, the assignment of the "coming-toaid" duty to the JEG in Juba became a practical agenda.

This does not necessarily mean, however, that Abe was particularly eager to assign "coming-to-aid" duty to the JEG. Indeed, Shinichi Kitaoka (2021), who played a leading role in the examination of the Security Experts Panels in 2008 and 2014, retrospectively commented as follows:

Some criticized that the [Abe] government was trying to deploy the SDF all over the world, but this was complete fabrication [...]. Rather, the Abe Cabinet was very cautious about [participation in] the UNPKOs, to the extent that they could be described as timid. (p. 2)

This contradicts the stereotyped understanding of Abe's posture in military and security policy, but Kitaoka's articulation supports the fact of the sudden withdrawal of the JEG from South Sudan, only a half year after the assignment of "coming-to-aid" duty.

Why, then, was Abe so cautious toward the PKO issue, despite his eager posture, as typified in the political slogan of "Proactive Contribution to International Peace"? It was probably because he was trying to avoid 
political risk in order to prioritize the realization of his cherished policy agendas, epitomized by the amendment to the Constitution. If the JEG personnel were injured and/or killed, or used weapons beyond the allowed range, this would have severely undermined the power basis of Abe's government, ruining his long-standing political ambitions: what Abe called "The Departure from the Post-war Regime," which was the all-inclusive reformation of Japan's existing political, economic, and social system, the basis for which was constructed soon after World War II (Abe, 2017).

The conservative politicians, including Abe, had long desired to implement such drastic reforms because they were dissatisfied with the existing postwar system, whose formation was led by the US occupation force. In particular, the amendment to the Constitution was regarded as the centerpiece among the various reform agendas because a large part of the supreme law was drafted and enforced by the Americans (Koseki, 1998; Winkler, 2011). ${ }^{1}$ Despite the conservatives' discontent, the majority of Japanese politicians and public opinion firmly supported the Constitution, especially regarding Article 9. This made the amendment an almost untouchable issue. As a result, the Constitution has never been amended.

When Abe returned to power at the end of 2012, however, he was blessed with an ideal opportunity to accomplish the amendment, since the ruling coalition occupied an overwhelming majority at the Diet: support from more than the two-thirds of the legislature was a prerequisite for the government to advance the procedure for the constitutional amendment (Prime Minister of Japan and His Cabinet, 1947, art. 96). Under such a situation, we can reasonably assume that Abe was inclined to prioritize this significant agenda of constitutional amendment, leaving the peacekeeping issue aside, even though he was ultimately unable to complete the amendment. Presumably, this was the true reason behind the withdrawal of the JEG in 2017, although this hypothetical argument must be confirmed by future historians.

We may also surmise the other possible reasons. One conceivable reason could be relatively close to the GoJ's official explanation for the withdrawal: the JEG had almost completed their assignments and there was not much left for them to do, and hence, it was an appropriate time for them to go home. This reasoning appears plausible because the GoJ initially intended to use the JEG for the "All Japan" approach, but this momentum was soon weakened with the outbreak of de facto civil war at the end of 2013, and was further lost due to another armed clash in 2016. It was particularly so because most of the Japanese development workers 
and the other civilian personnel, who were supporting the statebuilding of South Sudan, had to leave the young country following the armed clashes in 2013 and 2016. Given the switch of mandate from statebuilding to the PoC purpose, the JEG mostly engaged in the construction of PoC sites, but this was more or less an emergency relief operation and was not a long-term task to be maintained for several years. If so, one may regard the withdrawal in 2017 as a result of the lost momentum.

Alternatively, it might be possible to attribute the withdrawal, at least in part, to the regime change in the US at the beginning of 2017. Presumably, the GoJ decided to deploy the JEG to South Sudan partly out of consideration for the US ally, to boost their enterprise of supporting the independence of South Sudan (see Chap. 8). In January 2017, however, the US administration was taken over by President Donald Trump, who showed little interest in the UNPKOs. As a result, the GoJ's interest in the troop contribution to South Sudan had probably declined.

Another possible explanation could be that the GoJ had been disappointed at the hopeless future of South Sudan. At least partially, it seems true that the GoJ initially seemed to be pleased to support the self-reliance of the youngest country, but the trajectory of South Sudan's first decade has been mostly characterized by "conflict and hardship" (Sullivan, 2021). It would not be surprising if the GoJ had become skeptical about the extent to which its support was actually contributing to the self-reliance of the newly independent country.

Domestically, one might question whether Abe's own political scandal had affected the decision to withdraw, because a press conference relating to the so-called Moritomo Gakuen problem was held on the same day (March 10, 2017) as the press release about the JEG's withdrawal from South Sudan. Whatever the truth was, it seems almost certain that the decision to withdraw was made at the top political level, presumably by Abe himself, because it remained firmly confidential until the day of the press release.

\section{Japan's Shift to Capacity-Building Support}

Since the withdrawal of the JEG from South Sudan in spring 2017, the GoJ has thus far not deployed any new SDF contingents to a UNPKO. Neither have there been any signs of the GoJ seeking to make another SDF troop contribution, at least in the near future. Most of the UNPKOs are currently being operated in dangerous circumstances, mostly 
in Africa, and this makes it very difficult to satisfy the stringent stipulations of the PKO Act. Moreover, the UN's budget retrenchment for peacekeeping in recent months has led to successive closures of UNPKOs, such as those in Haiti, Côte D'Ivoire, Liberia, and Darfur (UNDPO, n.d.-a). The reduction in the whole scale of UNPKOs has made it even more difficult for Japan to find a suitable destination for its contributions.

Importantly, this challenge is not unique to Japan. In general, the countries in the Global North tend to share a similar problem of finding appropriate destinations for personnel contributions (see Chap. 1). As a result, many of them have shifted their focus from large-scale troop contribution, which is usually more dangerous, to the deployment of a small number of staff officers and individual experts, or to the provision of support outside of UNPKOs. Meanwhile, the countries in the Global South mostly share the burden of deploying large troop contingents to dangerous locations. During the last decade or so, the GoJ has placed increasing emphasis on capacity-building support, as clearly mentioned in the NDPG and the Mid-term Defense Program in 2009 and 2013 as well as the NSS issued in 2013. Under this framework, the MoD has provided various defense-related training and education (e.g., international maritime law, hygiene, vehicle and vessel maintenance, and bomb disposal) to the 15 Asia-Pacific countries (e.g., Indonesia, Uzbekistan, and Laos) and to a regional organization (Association of Southeast Asian Nations: ASEAN) (MoD, n.d.-a). In this line, the MoD has provided bilateral peacekeeping/IPC-related capacity-building support (e.g., engineering, maintenance of water purification plants, humanitarian assistance, and disaster relief) to these countries, including Cambodia, Thailand, Papua New Guinea, and Mongolia. These experiences have guided the GoJ in their search for a new direction. Accordingly, Japan has gradually changed its course from direct support, such as the contribution of the JEG, to indirect support, as exemplified by capacity-building training for peacekeepers contributed from developing countries.

The shift appeared as early as 2015 when the GoJ began to train military engineers from African countries in partnership with the UN Department of Operational Support under the multilateral framework of the Triangular Partnership Programme (TPP) (United Nations, 2021). This was based on Prime Minister Abe's pledge at the 2014 Leaders' Summit on Peacekeeping (see Chap. 4; MoFA, 2014). Following the JEG's withdrawal from UNMISS in 2017, the GoJ has been expanding the geographical and topical range of its capacity-building support. In 
2019 , for example, Japan began providing engineering training for peacekeepers, not only in Africa but also in Asia. In the same year, training provision for medical care was also added under the TPP framework. The first medical training on the use of first aid on site was provided in the UN Regional Support Center in Entebbe, Uganda (MoFA, 2019). In the early 2020s, a month-long engineering training course, with a special emphasis on a "Training of Trainers" component, was held in Vietnam for military personnel from various South and Southeast Asian countries (MoFA, 2020a).

In the same way as other advanced nations, Japan thus began to compensate for its shortage in personnel contributions to UNPKOs by instead providing its knowledge and expertise. This meant a clear departure from the traditional assumption underlying Japan's peacekeeping policy. The termination of JEG deployment to UNMISS in 2017 represented a virtual "death sentence" for existing assumptions about, and methods within, Japan's catch-up-oriented peacekeeping policy: to slowly and cautiously follow the trends of "integration" and "robustness" in the hope of making a more "proactive" contribution to UNPKOs. This incremental approach no longer works today, bringing Japan to a crossroads while raising the need to reconsider its entire UNPKO involvement. Accordingly, the GoJ changed course to primarily concentrate on indirect support contributions, especially capacity-building support to Global South peacekeepers.

\section{The Remaining Need \\ for Personnel Contribution}

\subsection{Ongoing Personnel Contribution from the Other Advanced Countries}

The situation discussed earlier does not necessarily mean, however, that the GoJ has completely abandoned the notion of future dispatch of military personnel. In general, the Global North countries contribute small numbers of highly qualified, well-educated personnel to provide knowledge, skills, and management, mainly at field headquarters. Meanwhile, the Global South countries tend to make large troop contributions, mostly of infantry, albeit not at a quality equivalent to those from the Global North.

No matter how dominant this demarcation is in practice, the Global North is not entirely free of the ethical problem of shirking dangerous 
duties that then fall upon those from less wealthy nations. Moreover, the military contribution to the UNPKOs not only fulfills practical duties on site but also could have a diplomatic impact to highlight the political commitment of troop-contributing countries to international peace and security. Furthermore, military deployment on the ground is also very important in providing firsthand field experience to the military personnel. For these reasons, the nations in the Global North are still confronting the necessity for "Boots on the Ground."

The Global North countries have not fully retreated from personnel contribution to UNPKOs. We can identify three current forms of military contribution from advanced states. First, small numbers of staff officers and/or experts (e.g., a judicial specialist), or even force commanders, are sent to UN missions. Arguably, this is the commonest form of personnel contribution from the Global North, since these posts are suitable for utilizing their knowledge and expertise and are usually tasked in a safer environment. Second, some states in the Global North restrict their troop contributions only to safer UNPKOs. Italy, for example, is making a largescale contribution of nearly 1000 military personnel to the United Nations Interim Force in Lebanon (UNIFIL) (UNDPO, n.d.-b), where the security situation is relatively stable. Third, parts of the Global North, especially European states, are deploying troops to the UNPKO in Mali, the UN Multidimensional Integrated Stabilization Mission in Mali (MINUSMA). For instance, Germany has sent more than 400 troops to Mali. This is an exceptional case, however, since Mali is located at the core of the Sahel region, which is often regarded as a hotbed of violent extremism that poses a direct threat to Europe. MINUSMA has a highly combatoriented nature geared toward tackling violent extremism, while it is also assigned as an integrated mission.

Japan, too, still recognizes military personnel contributions as a token of its commitment to international peace and security. For this reason, even after the JEG's withdrawal in 2017, it has maintained the deployment of four staff officers to UNIMSS. In fact, the GoJ has shown interest in deploying additional staff officers to the UNPKOs, but it remains difficult to find an appropriate mission for this purpose. On the one hand, staff officer posts are mostly full in the safer UN missions, as is also the case for troop contributions in safer destinations, such as Lebanon and Cyprus. On the other hand, the large-scale UN missions that may have vacant posts are mostly located in unstable locations around francophone Africa, such as in Mali, the DRC and the (Central African Republic) CAR. Although 
deploying staff officers seems to be one optimal policy option for the GoJ, the chance of this happening in practice seems slim destination in practice, especially because the deployment of staff officers to field headquarters usually goes hand-in-hand with troop contribution

Neither the second nor the third option mentioned above is suitable for personnel deployment from Japan. Other contributing states have already taken the preferable posts in relatively safe missions (the second option), while the GoJ has shown little interest in the deployment to MINUSMA (the third option), presumably given the combat-prone characteristics of the mission, as well as its lack of direct relevance to Japan's national security. In short, it seems difficult, if not impossible, for the GoJ to increase its personnel deployment within the UN framework.

\subsection{Japan's Personnel Deployment to Non-UN Peacekeeping Operations}

Given the difficulty of making the additional personnel deployment to UNPKOs, the GoJ has searched for alternatives, that is, making an SDF contribution to a non-UN mission. Since 2019, the GoJ has dispatched two staff officers to the Multinational Force and Observers (MFO) in the Sinai Peninsula (MoD, n.d.-c). Since 1982, the MFO has been operated as a non-UN peace operation to monitor a cease-fire between Egypt and Israel (MFO, n.d.-b). As of July 2021, 13 states are contributing troops to the MFO, among them the US, Norway, Fiji, and Columbia (MFO, n.d.-a). This dispatch is carried out as an "internationally coordinated operations for peace and security," which is a new category added to the amended PKO Act as part of the Peace and Security Legislation in 2015.

Other than that, there may be future possibilities of involvement in non-UN operations in other regions, again as an "internationally coordinated operations for peace and security." In Asia, for example, there is a precedent for non-UN peace operations in the Philippines. Since 2004, the International Monitoring Team (IMT) has been deployed to Mindanao to monitor the cease-fire between the Philippine government and the Muslim secessionist armed group known as the "Moro Islamic Liberation Front" (MILF). The IMT is made up of willing governments, mainly from the Muslim countries in the region (i.e., Malaysia, Indonesia, and Brunei), but also from other regions (i.e., Norway) as well as the EU. The IMT has operated outside of the UN framework, albeit with UN authorization 
under Chapter VIII of the UN Charter, which prescribes the partnership between the UN and regional arrangements.

Since 2006, Japan has also been involved in the IMT by contributing civilian personnel. More specifically, the JICA has contributed civilian experts to the IMT to facilitate the peace process. Previously, this kind of personnel contribution was restricted to civilian deployment, exemplified by the JICA experts, as seen above. Now that the "internationally coordinated operations for peace and security" have been formally institutionalized as part of the 2015 Peace and Security Legislation, it has become technically possible for the Japanese government to contribute not only civilians, but also military personnel. In March 2021, the GoJ retreated from the IMT, but instead deployed a former SDF officer to Mindanao with diplomatic (civilian) status to promote the DDR program for excombatants. This example implies that the deployment of retired military personnel with good skills and knowledge might be the optimal substitute for a troop contribution by the GoJ.

Legally, meanwhile, the International Peace Support Law, which is the only new law made within the package of Peace and Security Legislation (see Chap. 4), enables the GoJ to contribute the SDF if an international or multinational force is formed in the future, similar to an operation similar to the International Security Assistance Force (ISAF), that is, the US-led coalition force to stabilize Afghanistan. In reality, however, it seems very unlikely that this would happen, partly because the prior consent from the Diet was imposed to operationalize the law (see Chap. 4) and partly because the US, which had led the most of multinational military operations from the 1990s to the 2010s, has recently become more and more reluctant to organize such an international operation.

\section{Concluding Thoughts: Other Possible Alternatives And the Future Agenda}

In conclusion, we have confirmed that Japan's peacekeeping policy has reached a crossroads, symbolized by the abrupt termination of the UNMISS troop contribution in 2017. Throughout approximately a quarter-century history from 1992 to 2017 , SDF personnel contributions to UNPKOs served as a centerpiece in Japan's peacekeeping. With the stringent constraints embedded in the PKO Act, or more essentially in the Constitution, the GoJ faced repeated challenges to its military 
contribution and formed a restrained posture in Japan's peacekeeping policy. This created an assumption that Japan should make a more "proactive" contribution to the UNPKOs. To achieve this, the GoJ tried to pursue the international trends of "robustness" and "integration," albeit slowly and cautiously. Here lies an ever-developing premise: if it continues with its efforts to follow these trends, Japan will eventually be able to catch up with the international trend. The examination in this book has proven that the old premise above has become outdated. In other words, it is time to seek a new direction in Japan's peacekeeping policy beyond the pursuit of "robustness" and "integration."

All in all, what future prospects can we envisage? At this moment, we can at least say that the shift in Japan's peacekeeping (or more broadly in the IPC policy) from "quantity" to "quality" is highly unlikely to change in the foreseeable future. But this could be a favorable opportunity for Japan's peacekeeping policy to escape from the old obsession with more "proactive" military contribution and to be more flexible in the search for a new direction.

At the end of this book, we will briefly examine some future prospects. First, it seems almost certain and rational that Japan will place the greatest emphasis on capacity building in its peacekeeping/IPC policy, although this has been suspended since spring 2020 due to the COVID-19 pandemic. While waiting until it becomes possible to resume the program, it is recommended to consider how the current scheme can be improved. In particular, the current TPP framework faces challenges as a multinational scheme, in which each participant country has different needs and varying qualities of personnel. It would, therefore, be useful to develop a more detailed educational program to flexibly accommodate the demands of trainee countries.

Capacity-building support can be carried out in various forms other than the TPP. As seen earlier in this chapter, for example, the MoD has provided bilateral peacekeeping-related training, mainly to the Asian countries. Bilateral assistance often has an advantage in that it can provide tailor-made support to fit the needs of the recipient country, while UN-involved TPP has the merit of making a direct contribution to the UN. Given the different scopes and characteristics, it would be beneficial to develop bilateral capacity building along with the multilateral TPP framework. In addition, it would be highly advisable to expand the scope of bilateral capacity-building support to countries beyond the Asia-Pacific region, especially in Africa. 
The other possibility is to reinforce both financial and human support with regional peacekeeping training centers, again, especially in Africa. Since 2008, the MoD has deployed SDF peacekeeping instructors to African countries, such as Egypt, Mali, and South Sudan, as well as Asia, including India and Indonesia (with 33 deployments in total, involving 38 personnel; MoD, n.d.-b). In recent years, the MoD has most frequently deployed instructors to Ethiopia. In addition, the IPCH has also contributed civilian lecturers to those peacekeeping centers (Cabinet Office, n.d.).

Overall, these educational supports provide only one-off lectures or short-term lecture courses. It would be more desirable to provide more intensive training courses. In addition, it would also be highly beneficial to expand the training assistance in West Africa, where most of the UNPKOs are being operated today. For instance, through collaboration with the Kofi Annan International Peacekeeping Training Centre in Ghana, along with the existing ties with the Ethiopian International Peacekeeping Training Center, the GoJ's provision of training could cover both East and West Africa.

In the meantime, police-related activities in Japan's peacekeeping/IPC policy have been in constant decline since the capacity-building support to the East Timorese police in the early 2000s (see Chap. 6). The reluctance of Japanese police in the peacekeeping/IPC policy field is often attributed to the "trauma of Cambodia," in which a Japanese police officer was killed on duty (see Chap. 5), while the Japanese police have engaged in capacitybuilding support to adjacent countries and also to those that are not in the immediate aftermath of armed conflict, such as Indonesia, within a framework of development aid (JICA, n.d.). The Japanese police prefer capacity-building support, especially toward the Asian countries (not immediately after armed conflict), exemplified by Indonesia, not only because they are concerned about security but also because peacekeeping/ IPC-related tasks are not major concerns in the Police Act (Ministry of Internal Affairs and Communications, n.d.). ${ }^{2}$ That said, a legal amendment would be required to expand their role in the peacekeeping/IPC field: for example, to deploy individual police officers to support the capacity building of local police in the UNPKOs.

Apart from capacity building and training support (as well as financial assistance), as pointed out above, it is still desirable to maintain SDF deployment-particularly of the JEG - in some form, albeit not through large-scale contribution. In this regard, it seems most feasible to make 
more contributions under the framework of "internationally coordinated operations for peace and security." For this purpose, searching for a new destination, in addition to the current participation in the MFO, could be an option, but it might also be useful to pay attention to Japan's registration for the UN Peacekeeping Capability Readiness System (PCRS). According to the MoFA (2020b), the GoJ has registered the PCRS in four areas: the engineering force, military observers, staff officers, and strategic air transport (international transportation between logistics hubs). Among them, the fourth item, which was most recently added in May 2020, attracts attention, since there is a high demand in the recent UNPKOs for the provision of air transport capability (Novosseloff, 2017). Short-range air transportation above conflict-affected areas could be potentially dangerous, but longer-range transportation between international logistics centers is generally a safer option.

In this regard, air cooperation with Canada could be useful, particularly in Africa. As mentioned, Canada is one of the Global North countries that have recently taken a constrained posture toward personnel contribution to the UNPKOs. To compensate for this, Canada has recently contributed air assistance to MINUSMA in Mali and to the UN Regional Service Centre Entebbe (RSCE) in Uganda. Although Canada's provision of air assistance is connected to their personnel contribution to Africa (dozens of individual police officers, staff officers and experts to Mali, the DRC and South Sudan), Japan may be able to provide additional air transport capability to compensate when the Canadian air assistance is not available-for example, in rotation (M. Tsuzuki, personal communication, July 9, 2021).

Related to this, it would also be worthwhile examining the possibility to utilize the SDF's base in Djibouti. The threat of Somali piracy, which was the original reason for the construction of the base, has become much less visible in recent years, but the location of this African nation has significant strategic importance. In fact, the NDPG in 2018 emphasized the importance of "stable, long-term use of the facility for regional security cooperation and other activities" (MoD, 2018, p. 18), which reflects the GoJ's will to utilize the Djibouti base even after the necessity for counterpiracy has largely declined. One of the possibilities could be to use the Djibouti base as the strongpoint for the above-mentioned air transportation service in Africa. If this mechanism were established, it could be utilized not only for assistance to the UNPKOs but also in times of emergency evacuation of Japanese nationals in Africa and the Middle East (M. Tsuzuki, personal communication, July 9, 2021). 
In the meantime, it may not be entirely impossible to contribute the SDF to the relatively safer posts or UNPKOs. For example, UNIFIL is an exceptional UNPKO in the sense that it has maritime capability (UNDPO, n.d.-c). Japan's maritime ability might usefully contribute to this (M. Tsuzuki, personal communication, July 9, 2021). Moreover, as said earlier, the positions of staff officers tend to be full, but missions sometimes have vacancies, to which the GoJ could contribute. Furthermore, the GoJ could also contribute civilian experts, especially to support judicial reform in the UNPKOs.

Last but not least, it should be remembered that the Global North, including Japan, can focus on quality-oriented activities because the Global South accepts the large-scale and dangerous roles, especially in Africa. Japan must consider seriously how to mitigate their burdens, particularly concerning the safety of personnel on site, as the Cruz Report warned in 2017.

As seen so far, there are still various prospects for Japan's future peacekeeping, or more broadly, for its IPC policy, but these ideas would be never realized without political will and public support to endorse the "future investment." As repeatedly pointed out in this book, the Japanese government and public have been more attracted to regional and national security issues, but this does not entirely extinguish the importance of peacekeeping and IPC issues in the longer term.

Myopic reductions in political and financial investments in this area could undermine Japan's longer-term strength and preparedness for crisis. Very recently, the GoJ's reduction in budgetary and political support to the vaccination industry has caused a serious delay in the development of a national vaccination program for COVID-19 (“'Iryo-senshin-koku' no hazu," 2021). To avoid such failures, it is critical to nurture long-term prospects and encourage the GoJ to invest for the future, in terms of both financial and human resources. We now conclude this book with the hope that it will make at least some contribution to bringing about such positive change.

\section{Notes}

1. In the initial days of the second Abe administration, there seemed to exist a high possibility that the amendment could be achieved, but Abe gradually lost his power due to a series of political scandals (e.g., the incident of the "Cherry Blossom Viewing Party" and the educational institute Moritomo 
Gakuen scandal), as well as the poor response to COVID-19. Given these backlashes, Abe's health condition rapidly deteriorated in summer 2020. He eventually resigned in September 2020, although it was originally expected that he would remain in power until September 2021 when his term as the president of the ruling LDP would expire.

2. The Police Act envisages international cooperation more specifically in relation to criminal justice, such as international criminal investigation and communication with the International Criminal Police Organization (Article 23 (2) 1,2 ) while also mentioning international emergency relief, which is a part of broader IPC (Article 5 (4) 11).

\section{REFERENCES (In ENGLISH)}

Koseki, S. (1998). The birth of Japan's postwar constitution (R. A. Moore, Trans.). Westview Press.

MFO. (n.d.-a). Military personnel by country. Retrieved July 11, 2021, from https://mfo.org/contingents

MFO. (n.d.-b). Welcome to the multinational force \& observers. Retrieved July 11, 2021, from https://mfo.org/

MoD. (2018, December 18). National defense program guidelines for FY 2019 and beyond. https://www.mod.go.jp/j/approach/agenda/guideline/ pdf/20181218_e.pdf

MoFA. (2014, September 29). Summit meeting on UN peacekeeping operations (PKO). https://www.mofa.go.jp/fp/ipc/pagele_000035.html

MoFA. (2020a, January 21). Dispatch of Japan ground self-defense force to training of the UN triangular partnership project (Asia and the surrounding regions). https://www.mofa.go.jp/press/release/press4e_002759.html

Novosseloff, A. (2017, October). Keeping peace from above: Air assets in UN peace operations. International Peace Institute. https://www.ipinst.org/wp-content/ uploads/2017/10/1710_Keeping-Peace-from-Above-1.pdf

Prime Minister of Japan and His Cabinet. (1947, November 3). The constitution of Japan. https://japan.kantei.go.jp/constitution_and_government_of_japan/ constitution_e.html

Sullivan, R. (2021). South Sudan ten years on: Serious challenges remain after a decade of conflict and hardship. Independent (online). https://www.independent.co.uk/independentpremium/south-sudan-10th-anniversary-featurebl $880436 . h t m l$

The Advisory Panel on Reconstruction of the Legal Basis for Security [The Security Experts Panel]. (2014, May 15). Report of the Advisory Panel on Reconstruction of the Legal Basis for Security. Prime Minister of Japan and His Cabinet. https:/ / www.kantei.go.jp/jp/singi/anzenhosyou2/dai7/houkoku_en.pdf 
UNDPO. (n.d.-a). Past peace operations. United Nations Peacekeeping. Retrieved July 11, 2021, from https://peacekeeping.un.org/en/past-peacekeepingoperations

UNDPO. (n.d.-b). Troops and police contributors. United Nations Peacekeeping. Retrieved July 11, 2021, from https://peacekeeping.un.org/en/troop-andpolice-contributors

UNDPO. (n.d.-c). UNIFIL: United Nations interim force in Lebanon. United Nations Peacekeeping. Retrieved July 11, 2021, from https://unifil.unmissions.org/unifil-maritime-task-force

United Nations. (2021, January 6). Triangular partnership programme: Fact sheet. https://operationalsupport.un.org/sites/default/files/210106_tpp_ factsheet.pdf

Winkler, C. G. (2011). The quest for Japan's new constitution: An analysis of visions and constitutional reform proposals, 1980-2009. Routledge.

\section{REFERENCES (In JAPANESE)}

"Iryo-senshin-koku" no hazu no nihon, naze okureru kokusan-wakuchin-kaihatsu: Gijutsu sodatezu "chikuseki nashi" [Why has the vaccine development been delayed in the medically advanced Japan?: The outcome of placing less value on medical technology development]. (2021, April 18). Yomiuri Shimbun (online). https://www.yomiuri.co.jp/medical/20210413-OYT1T50210/

Abe, S. (2017, June 27). Shugi-in-giin Motomura Kentaro-kun teishutsu, sori no iu "sengo-rezimu" no imi ni kansuru shitsumon ni taisuru toben-sho [GoJ's response to the questionnaire submitted by the member of the House of the Representatives Kentaro Motomura concerning what Prime Minister Abe called the "Postwar Regime"]. https://www.shugiin.go.jp/internet/itdb_shitsumon_pdf_t.nsf/html/shitsumon/pdfT/b193431.pdf/\$File/b193431.pdf

Cabinet Office. (n.d.). Kokusai-heiwa-kyoryoku-kenkyu-in nado ni yoru kogi-to no jisseki [Actual performance of lectures by IPC researchers]. The Internatioal Peace Cooperation Headquaters Secretariat. Retrieved July 11, 2021, from http://www.pko.go.jp/pko_j/organization/researcher/researcherl l.html

JICA. (n.d.). Shimin-keisatsu-katsudo (POLMAS) zenkoku-tenkai-purojekuto fezu-2 [Project on nationwide capacity development of police officers for POLMAS-Indonesian civilian police activities phase 2]. ODA mieru-ka site. Retrieved July 1 1,2021, from https://www.jica.go.jp/oda/project/1700569/ index.html

Kitaoka, S. (2021, March 11). "Gaiko to anzen-hosho" ni Abe-naikaku ga nokoshita regashi: "Ampo-hosei" "Sengo-70-nendanwa" "FOIP" toin seika [The Abe Cabinet's legacy in "diplomacy and security"-The achievements of "Peace and Security Legislation," "narrative after seven decades since the end of World War II," and the "free and open Indo-Pacific"]. Toyo Keizai Online. https:// toyokeizai.net/articles/-/413415 
Ministry of Internal Affairs and Communications. (n.d.). Keisatsu-ho [Police Act]. E-gov. https://elaws.e-gov.go.jp/document?law_unique_id=329AC00000 00162_20200401_429AC0000000029

MoD. (n.d.-a). Noryoku-kochiku-shien-jigyo [Capacity building assistance program]. Ministry of Defense / Self-Defense Forces. Retrieved July 11, 2021, from https://www.mod.go.jp/j/approach/exchange/cap_build/

MoD. (n.d.-b). PKO-kunren-senta eno jiei-kan no koshi-to baken [Dispatch of SDF lecturers to PKO training centers]. Ministry of Defense / Self-Defense Forces. Retrieved July 11, 2021, from https://www.mod.go.jp/j/approach/kokusai_ heiwa/pko/pko_center.html

MoD. (n.d.-c). Shinai-hanto-kokusai-heiwa-kyoryoku-gyomu (Kokusai-renkeiheiwa-anzen-katsudo) [Cooperation on international peace in the Shinai Peninsula]. Ministry of Defense, Self-Defense Forces. Retrieved July 11, 2021, from https://www.mod.go.jp/j/approach/kokusai_heiwa/pko/201904_ egy.html

MoFA. (2019, October 2). Nihon to kokuren ni yoru PKO-yoin ni taisuru iryokunren no kaishi (Kokuren-sankaku-patonashippu-purojekuto) [Launch of medical training program for PKO personnel by Japan and the UN (TPP project)]. https://www.mofa.go.jp/mofaj/press/release/press4_007877.html

MoFA. (2020b, June 2). Kokuren-heiwa-iji-katsudo-sokuno-noryoku-toroku-seido [UN peacekeeping capability readiness system (PCRS)]. https://www.mofa. go.jp/mofaj/fp/ipc/page25_000358.html

Open Access This chapter is licensed under the terms of the Creative Commons Attribution 4.0 International License (http://creativecommons.org/licenses/ by $/ 4.0 /$ ), which permits use, sharing, adaptation, distribution and reproduction in any medium or format, as long as you give appropriate credit to the original author(s) and the source, provide a link to the Creative Commons licence and indicate if changes were made.

The images or other third party material in this chapter are included in the chapter's Creative Commons licence, unless indicated otherwise in a credit line to the material. If material is not included in the chapter's Creative Commons licence and your intended use is not permitted by statutory regulation or exceeds the permitted use, you will need to obtain permission directly from the copyright holder.

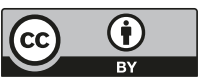

